\title{
To Be or Not to Be at Home. Heidegger and Derrida reading Sophocles
}

\section{Diego D'Angelo}

\begin{abstract}
In the 1940s, Martin Heidegger held a series of lectures in which he interprets passages from Sophocles' Antigone in order to understand the characterization of the human being as deinon, which Heidegger translates as unheimlich or "not at home." This essential determination of the human being as a being which is constitutively not-at-home will be discussed in the first part of this paper. In the second part, I will discuss Jacques Derrida's reading of another Sophoclean text, Oedipus at Colonus, in order to discuss the question of Oedipus's foreignness. Heidegger's and Derrida's readings of Sophocles do have different approaches and methodologies, but considering the influence of Heidegger on Derrida's thought, it is possible to find deep similarities, connections, and philosophically relevant divergences. This confrontation of the two readings concerning the question of being-at-home and foreignness will show that their approaches complement each other.
\end{abstract}

Keywords: Heidegger, Derrida, Sophocles, Oedipus

Aus der Hand frißt der Herbst mir sein Blatt: wir sind Freunde. Wir schälen die Zeit aus den Nüssen und lehren sie gehn: die Zeit kehrt zurück in die Schale.

Autumn eats a leaf from my hand: we are friends. From the nuts we shell time, and we teach it to walk: time returns to the shell. Paul Celan, Corona hat does it mean for humans to be or to feel "at home"? We can be at home in a certain country, which may but must not be our native country; but we may also feel like strangers in our own

(C) 2021 Diego D'Angelo

https://www.kritike.org/journal/special issue 2021/d'angelo april2021.pdf

ISSN 1908-7330 
country. Moreover, we may feel "at home" in certain situations rather than in others, when we are surrounded by certain people, or just when we have to carry out a certain task with which we are "familiar."

In the following, I will try to shed some light on this problem by choosing a particular hermeneutical path within philosophical works of the $20^{\text {th }}$ century. The problem of feeling "at home" concerns humans as such, and this is the reason why we can encounter descriptions and examples of this in the earliest traces of written human culture-it is enough to mention the figure of Odysseus and his long-postponed longing for being back home in Ithaca after the Trojan War. The eternal fascination with this question shows itself precisely in the fact that such texts are being read and reinterpreted also today, making apparent that, even some 3,000 years after Odysseus, we are still grappling with the question of what it means to be at home and of why we strive so much for everything "familiar." Indeed, philosophy really seems to address directly this problem already with Socrates, who in the Apology claims that he is like a stranger before the tribunal that will condemn him to death. His feeling of being a foreigner is based on the fact that he does not speak the language of the tribunal, i.e., the language of Athenian justice. ${ }^{1}$ And one could go on tracing the history of a philosophy of homeness and foreignness up to Augustine of Hippo, an Algerian that moved to Carthage, Rome and Milan to live a life away from home. In the last century Jacques Derrida follows - at least to some extent-his steps and moves from Algeria to Paris. He also writes extensively on the question of being at home, being a stranger, and the rights of strangers in a foreign country.

Quite an opposite tradition sees philosophers not as wandering between different countries, but as sedentary and unwilling to move. Socrates himself is not willing to leave Athens and prefers death to exile. In modern times, Martin Heidegger basically never left Southern Germany and his beloved Black Forest. He spells out his reasons in his short writing "Why Do I Stay in the Provinces?" where he claims that his philosophical work is deeply connected with the region he lives in: "The inner relationship of my own work to the Black Forest and its people comes from a centuries-long and irreplaceable rootedness in the Alemanian-Swabian soil." 2

But even from this quite different perspective, Martin Heidegger left extensive considerations on what it means for humans to be at home. Some of them seem to point in a direction different than this rootedness in one's own country in order to stress how the human being is essentially a stranger, and I will try to thematize this "other Heidegger" here. This paper will deal with the question of being at home in Heidegger and Derrida as two different

\footnotetext{
${ }^{1}$ Plato, Apology 17c-d.

2 Martin Heidegger, "Why Do I Stay in the Provinces?," in Heidegger: The Man and the Thinker, ed. by Thomas Sheehan (New York: Routledge 2009), 17.

(c) 2021 Diego D'Angelo https://www.kritike.org/journal/special issue 2021/d'angelo april2021.pdf ISSN 1908-7330
}

(cc) BY-NC-ND 
philosophers that are nonetheless in the same tradition - as is well known, Derrida was heavily influenced by Heidegger's writing. In order to determine more precisely the scope of this paper, I will focus only on a particular part of their writings on being-at-home. Interestingly, both philosophers take as their point of departure in this question a reading of Sophocles and his Theban plays, which include Oedipus Rex, Antigone, and Oedipus at Colonus. However, although Sophocles is a common point of reference for Heidegger and Derrida when discussing what it means to be at home, they depart as to the selection of the work to which they mostly refer: Heidegger focuses on Antigone, Derrida on Oedipus at Colonus. ${ }^{3}$

In the 1940s Martin Heidegger held a series of lectures at the University of Freiburg in which he interprets passages of Sophocles' Antigone in order to understand the characterization of the human being as deinon. This concept is translated by Heidegger into German as "unheimlich," which can mean "monstrous," but also "not at home." Here, Heidegger tries to discover an essentially ethical determination of the human; indeed, he famously claims in the Letter on Humanism that "the tragedies of Sophocles - provided such a comparison is at all permissible-preserve the ethos in their sagas more primordially than Aristotle's lectures on 'ethics.'"4 As is well-known, in his later philosophy Heidegger turns to the Greeks even more intensively than in his earlier writings, ${ }^{5}$ and his interpretation of Sophocles is inscribed in his general interest in the "first inception" of thinking in Greek philosophy and literature.

This essential determination of the human being as a being which is constitutively not-at-home will be discussed in the first part of this paper. Heidegger deals with the not-being-at-home of the singular, individual human being, but does not put this in relation with the Other: What about the stranger? That is, what about human beings other than us?

In the second part, I will deal with Derrida's reading of another Sophoclean text, Oedipus at Colonus, in order to discuss the question of Oedipus's foreignness when he arrives, accompanied by his daughter Antigone, from Thebes to Colonus. What does it mean to be a foreigner, to be "not at home"? What does asking for asylum and rendering hospitality

${ }^{3}$ On Derrida and antiquity, see Miriam Leonard ed., Derrida and Antiquity (Oxford: Oxford University Press, 2010). On Heidegger and the Greeks, see Drew A. Hyland and John P. Manoussakis eds., Heidegger and the Greeks: Interpretative Essays (Bloomington: Indiana University Press, 2006).

${ }^{4}$ Martin Heidegger, Pathmarks (Cambridge, MA: Cambridge University Press 2008), 269. See also Norman K. Swazo, "Preserving the Ethos': Heidegger and Sophocles' Antigone," in Symposium, 10 (2006), 441-471.

${ }^{5}$ For a recent overview of the later Heidegger, see Günter Figal, Diego D'Angelo, Tobias Keiling, Guang Yang eds., Paths in Heidegger's Later Thought (Bloomington: Indiana University Press, 2020).

(c) 2021 Diego D'Angelo

https://www.kritike.org/journal/special issue 2021/d'angelo april2021.pdf

ISSN 1908-7330 
imply? Being a foreigner and being not at home, according to Heidegger, are both essential traits of the human being, and Derrida shows this very concept of the foreigner to be affected by a deep dichotomy: he would go on to show that the aim is not to find a solution to the dichotomy, but to inhabit the paradox.

Heidegger's and Derrida's readings of Sophocles do differ from each other in approach and methodology, but-also keeping in mind the influence of Heidegger on Derrida's thought - it is possible to find deep similarities and philosophically relevant divergences. This confrontation of the two readings will be the topic of the third part of the paper. Here, I will show that the impossible definition of the human being as "not-being-at-home" (deinon) does not represent a tension to be conceptually solved, but a tension we need to live in and "make our own": by accepting our constitutive foreignness, we can open up a realm where absolute hospitality becomes possible again.

\section{Heidegger's Reading of Antigone: The Human Being is Always Not at Home}

In the following, ${ }^{6} \mathrm{I}$ will concentrate on Heidegger's reading of Sophocles' Antigone as it takes place in the 1942 summer semester lectures on Friedrich Hölderlin's poem "The Ister." Heidegger already interpreted Sophocles' Antigone in his more famous lecture Introduction to Metaphysics, where his interpretation of Antigone is much less extensive and detailed than in the 1942 lectures, but has received more consideration in subsequent philosophical literature because of its political meaning. ${ }^{7}$ For the purpose of this paper, I will focus on the 1942 lectures. Here, Heidegger takes into account especially the second chorus of Antigone, where-in the very first verse-human is defined as deinon, unheimlich, or "uncanny."

The guiding idea of the first section of the present essay is that the determination of the essence of the human being as the "most uncanny of the uncanny" brings with itself a normative dimension, which is a kind of historical normativity: in order to be human, we must be uncanny in the very

${ }^{6}$ A first version of the argument and analysis presented in this section has already been published in German in Diego D'Angelo “Das Gesetz des Ortes. Ein Versuch über Heidegger und Sophokles," in Regelfolgen, Regelschaffen, Regeländern. Die Herausforderung für Auto-Nomie und Universalismus durch Ludwig Wittgenstein, Martin Heidegger und Carl Schmitt, ed. by Manuela Massa, James Thompson, Stefan Knauß, Matthias Kaufmann (Berlin: Peter Lang, 2020).

${ }^{7}$ On this, see Katie Fleming, "Heidegger's Antigone: Ethics and Politics," in Tragedy and the Idea of Modernity, ed. by Joshua Billings and Miriam Leonard (Oxford: Oxford University Press 2015). A close confrontation between the interpretations of Antigone in both lectures will be the topic of a subsequent paper, in which I will claim that Heidegger revised his interpretation in the aftermath of his delusion with the Nazi regime after his Rectorate.

(c) 2021 Diego D'Angelo

https://www.kritike.org/journal/special issue 2021/d'angelo april2021.pdf

ISSN 1908-7330

(c) BY-NC-ND 
special sense of unheimlich, as not being at home in a certain time and place. Being human means, in other words, not being at home.

It is precisely this normative dimension of not-being-at-home that lies at the heart of Heidegger's interest in reading Antigone: "If we explicate the choral ode in such a way, then we are thinking always in the direction of illuminating the essence of ... the fundamental law of becoming homely." ${ }^{8}$ In speaking of his own interest in reading Antigone as related to a fundamental law (Grundgesetz), Heidegger is very precise in the choice of his concepts. Indeed, in relation to Hölderlin's The Ister (which is the prime object of his analysis in this lecture) he marks a clear distinction between law (Gesetz) and rule (Regel):

In the fragment we are dealing with, Hölderlin names the law of being unhomely as the law of becoming homely. The law (Gesetz) is that essential trait (Wesenszug) into which the history of a historical humankind is placed (gesetzt). In the law, therefore, this distinguishing trait must be named. Otherwise, it remains a mere rule in the realm of the indeterminate. ${ }^{9}$

Unlike rules - as this passage seems to suggest-laws have historical traits in which the whole essence of the human being is implied. Rules are transient, but laws (and even more so basic laws, Grundgesetz) are concerned with the essence of the human being.

As is well known, the central verse of Antigone for Heidegger's

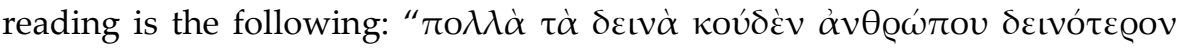
$\pi \varepsilon ́ \lambda \varepsilon \iota, "$ which Heidegger translates as, "Vielfältig das Unheimliche, nichts doch / über den Menschen hinaus unheimlicher waltet."10 This verse has been translated into English by William McNeill and Julia Davis as follows: "Manifold is the uncanny, yet nothing / beyond the human being prevails more uncannily." 11

At this point I will not go into the details (and difficulties) in Heidegger's translation, as this has already been done in scholarly literature. ${ }^{12}$ My question does not concern the correctness of Heidegger's philology but

${ }^{8}$ Martin Heidegger, Hölderlin's Hymn "The Ister," trans. by William McNeill and Julia Davis (Bloomington: Indiana University Press 1996), 60; Martin Heidegger, Hölderlins Hymne "Der Ister," (Frankfurt am Main: Klostermann, 1984), 73.

${ }^{9}$ Ibid., 133; Ibid., 166.

${ }^{10}$ Heidegger, Hölderlins Hymne "Der Ister," 64-65.

${ }^{11}$ Heidegger, Hölderlin's Hymn "The Ister," 52; Hölderlins Hymne "Der Ister," 64-65.

${ }^{12}$ Cf. Otto Pöggeler, Schicksal und Gedichte: Antigone im Spiegel der Deutungen und Gestaltungen seit Hegel und Hölderlin (München: Fink Verlag, 2004); Vladimir Vukićević, Sophokles und Heidegger (Stuttgart/Weimar: Verlag J. B. Metzler, 2003).

(c) 2021 Diego D'Angelo

https://www.kritike.org/journal/special issue 2021/d'angelo april2021.pdf

ISSN 1908-7330 


\section{TO BE OR NOT TO BE}

tries to understand his philosophy. The crucial point of Heidegger's interpretation of Antigone lies in his own understanding of the German word "unheimlich." Although "uncanny" is the most frequent (and correct) translation, Heidegger is mostly concerned-as is often the case with his understanding of words and concepts - with the etymology of the word "unheimlich." He interprets the "uncanniness" of the uncanny as not-beingat-home. Indeed, the German word "unheimlich" is composed by the term "heim" - which means "home" (we can think about "Heimat" meaning as much as "homeland") - and the negating prefix " $u n$ ": strictly speaking, uncanniness means for us the feeling of not being at ease or not being at home in a certain situation. "Unheimlich" is also directly linked to "heimisch," which means "native."

The question to be raised at this point concerns what is meant by "home." Is not-being-at home necessarily uncanny? And is home a place, a feeling, a certain situation, or could it consist of being in a certain company, with certain people rather than others? For Heidegger, "home" is nothing of the kind. The concept of home impinges not on feelings or on space, but on time. Both the uncanny (unheimlich) and the native (heimisch) are not to be understood in the sense of the geographical home, as the everyday use of language would suggest, but they take place "within history." 13 This history, in turn, carries a "necessity" within itself. ${ }^{14}$ To put it differently: there is a necessity within history, which determines what being native and/or uncanny mean. This therefore has to do with history and temporality, and not with geography and space.

The human is uncanny. Being uncanny means: not being at home at a particular historical time. But why is this so? In order to elucidate what the necessity in historicity may be, we must take some steps Heidegger does not undertake himself in his interpretations of Antigone.

The essence of the human being is associated with the "beasts" in the antistrophe of Sophocles' play: The human being, insofar as he/she is

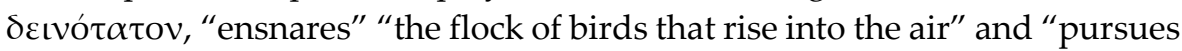
the animals of the wilderness and of the ocean's surging waves." ${ }^{15}$ Although this is lost in the English translation, in German animals and the waves of the ocean are said to be "heimisch," at home. Therefore, the human being, according to the choral song - and this is an analysis that Heidegger does not make himself -is uncanny precisely because he/she hunts the native, the animals. Indeed, the antistrophe goes on saying that the human is "most ingenious" because "he [sic] overpowers with cunning the animal / that roams in the mountains at night, / the wild-maned neck of the steed, / and the

\footnotetext{
${ }^{13}$ Heidegger, Hölderlin's Hymn “The Ister," 56; Hölderlins Hymne “Der Ister, " 69-70.

${ }^{14}$ Ibid., 56; Ibid., 69-70.

${ }^{15}$ Ibid., 50; Ibid., 63.
} 
never-tamed bull, fitting them with wood, he forces under the yoke."16 Clearly, this passage should be read in connection with the well-known distinction that Heidegger makes in his 1929/30 lectures Fundamental Concepts of Metaphysics: World, Finitude, Solitude. The human builds a world ("der Mensch ist weltbildend"), ${ }^{17}$ which is why he/she is characterized here as "most ingenious": human beings are not just delivered to their own world, as animals are, but they actively shape the world in which they live. But precisely because the human world can be transformed and is continuously transformed in the course of history, the human being is never really "at home." The world that he/she inhabits will be a different world tomorrow. Therefore, it is the ingeniousness of the human that carries her/his uncanniness as a consequence. On the contrary, animals are "poor in world" (Weltarm) because they only know their surrounding world without the capacity to change its structure, but precisely because of this they are "native" in their own world - they are at home because their world is stable and does not change with history.

If understood in this way, it seems now plausible to say that the uncanniness of the human is connected to time rather than to a place: human beings are uncanny in a temporal-historical, not geographical way. The human being is always already uncanny because he/she can change the world he/she lives in and because in this ever-changing world he/she will never be at ease or at peace.

This reading is confirmed by the following lines of the second strophe of the song of the Theban elders: "... He has found his way / into the sounding of the word /and swift understanding of all." ${ }^{18}$ Human beings are capable of this: speaking (about the world) and understanding (the world itself), which are presuppositions in order to change it. And the way in which this transformation of the world happens is through the construction of cities: humans have found their way "even into courageous / governance of the towns."19

Is the connection between thinking and speaking, on the one hand, and the construction and domination of cities, on the other, coincidental? Not at all, according to Heidegger. Since human beings speak and think, they form a world, and therefore they are uncanny in this ever-changing world, as shown before. But the human being always attempts again to become "native." He/She founds or conquers cities in which he/she can live and over

\footnotetext{
${ }^{16}$ Ibid., 59; Ibid., 74.

${ }^{17}$ Cf. Martin Heidegger, The Fundamental Concepts of Metaphysics: World, Finitude, Solitude, trans. by William McNeill and Nicholas Walker (Bloomington: Indiana University Press, 2001).

${ }^{18}$ Heidegger, Hölderlin's Hymn "The Ister," 60; Hölderlins Hymne "Der Ister," 73.

${ }^{19}$ Ibid.; Ibid.
} 


\section{TO BE OR NOT TO BE}

which he/she can rule; he/she founds (forms, shapes) his/her homeland, for essentially, he/she has none.

But, of course, he/she does not succeed in this attempt to become

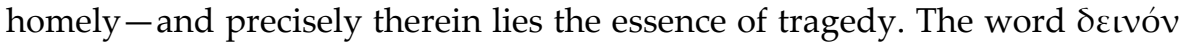
itself has, according to Heidegger, essentially a twofold character: "We may already gather from this that something counterturning prevails in what the Greeks name $\delta \varepsilon เ v o ́ v . " 20$ This counterturning character of $\delta \varepsilon \imath v o ́ v$ is also stressed by the chorus itself, which speaks of this diversity by naming $\delta \varepsilon เ v o$ ov in the plural form: $\pi 0 \lambda \lambda \dot{\alpha} \tau \dot{\alpha} \delta \varepsilon เ v \alpha \dot{\alpha}-$ "manifold is the uncanny." 21

This multiplicity and reciprocity belong to the very essence of the human being as the most uncanny. Thus, Heidegger says on the ambiguity of this term: "In that case, Sophocles' word, which speaks of the human being as the most uncanny being, says that human beings are, in a singular sense, not homely, and that their care is to become homely." ${ }^{22}$ This is confirmed by a central verse: "überall hinausfahrend unterwegs erfahrungslos ohne Ausweg kommt er zu Nichts"; "Everywhere venturing forth underway, yet

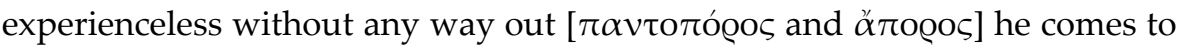
nothing." 23

The human being essentially remains on the move, with no way out. However, this absence of a way out does not motivate humans to search for a way out that leads away from a certain place (since human uncanniness is a temporal, not geographical phenomenon), but rather to a search for a way out of human "placelessness" in general.

The essence of man as $\delta \varepsilon เ v o ́ \tau \alpha \tau o v$ is, one could say, a normative reinterpretation of the Aristotelian definition. The Aristotelian definition is purely descriptive, because it says what man is and has, namely, language. The definition that Heidegger gets from Sophocles describes the (verbally understood, not substantial) essence of man by saying how the human being is (west, from the verb wesen) and has to be (sein): to be, for humans, means not being able to leave their placelessness. Humans must remain on their way: they build cities to escape their placelessness, but at some point they must move on. This "must" expresses the normativity implicit in

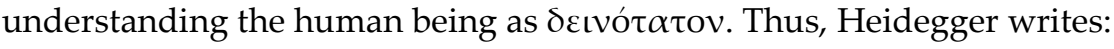

Yet this is no mere homeless wandering around that merely seeks a location in order then to abandon it and take its pleasure and satisfaction in a mere traveling around. The human being here is not the adventurer

${ }^{20}$ Ibid., 63; Ibid., 77.
${ }^{21}$ Ibid., 60; Ibid., 73.
${ }^{22}$ Ibid., 71; Ibid., 87.
${ }^{23}$ Ibid., 72; Ibid., 88.

(c) 2021 Diego D'Angelo

https://www.kritike.org/journal/special issue 2021/d'angelo april2021.pdf

ISSN 1908-7330

(c) BY-NC-ND 
who remains homeless on account of his lack of rootedness. Rather, the sea and the land and the wilderness are those realms that human beings transform with all their skillfulness, use and make their own, so that they may find their own vicinity through such realms. The homely is sought after and striven for in the violent activity of passing through that which is inhabitual with respect to sea and earth, and yet in such passage the homely is precisely not attained. ${ }^{24}$

Now, what has just been said can be combined with the necessity of history and of time which was briefly mentioned earlier. It is precisely because the human being is constantly on the move, and indeed because he/she must be on the move, that he/she experiences his/her own temporality as the temporality of being on the move. This temporality is the basis of history: the history of the founding of places and of migrations to which the human being is forced by her/his nature.

For there is, according to Heidegger in this lecture on Hölderlin, a "law" and a "structural articulation" of "the manner in which the world as a whole is opened up to human beings in general. As a consequence of, and in each case in accordance with this openness, human beings themselves are thus open to the world." 25 This law and structural articulation is the law of history, which is nothing other than the law of placelessness; this in turn is determined by the normatively understood nature of man. The "as yet concealed law of a concealed history" 26 corresponds to the law of placelessness: the place in which humans dwell must be left again and again, and this is so because the human being speaks and thinks.

That being which is most uncanny, i.e., the human being, is thus,

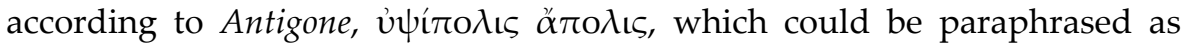
follows: humans found cities because they are not at home in any city. As seen before, in his explanation of Hölderlin's hymn "The Ister," Heidegger comes to connect the uncanny explicitly with the concept of place. In this sense, the essence of place is that "at which our becoming homely arrives, yet from which, as a coming to be at home, it also takes its departure." 27 This going in and out of a place is the law of being-not-at-home as the law of human uncanniness:

${ }^{24}$ Ibid., 73; Ibid., 89.

${ }^{25}$ Ibid., 23; Ibid., 26.

${ }^{26}$ Ibid., 24; Ibid., 28.

${ }^{27}$ Ibid., 35; Ibid., 42. 
This coming to be at home in one's own in itself entails that human beings are initially, and for a long time, and sometimes forever, not at home. And this in turn entails that human beings fail to recognize, that they deny, and perhaps even have to deny and flee what belongs to the home. Coming to be at home is thus a passage through the foreign. And if the becoming homely of a particular humankind sustains the historicality of its history, then the law of the encounter (Auseinandersetzung) between the foreign and one's own is the fundamental truth of history, a truth from out of which the essence of history must unveil itself. ${ }^{28}$

As it now becomes evident, if lawfulness is conceived in this way, space and time, geography and history collapse and become moments of the same normative structure.

In order to sum up the results of this first section, one can say that, according to Heidegger's reading of Antigone and "The Ister," the essence of the human being is not descriptive, stating something that humans have and other living beings do not (such as in Aristotle's definition of the human being as that being which has $\log o s)$, but rather normative. The essence of the human says what humans have to be: uncanny in their constant not-being-at-home. And this is precisely the reason why Antigone is for Heidegger an "authentic" individual. ${ }^{29}$ This law is the law of that history which humans create: history is the story of the continuous journey between what is foreign and what is one's own.

But what does it mean to be foreign? Indeed, Heidegger spends a great deal of fascinating analysis on the uncanniness of the human being and on being at home and not being at home. Nevertheless, the word "strange" (fremd) does not appear even once in these lectures. It is certainly right to assume that Heidegger's philosophy, for the way in which it conceives of Dasein and of being-with (Mitsein), does not need the concept of the foreign. ${ }^{30}$ But in a systematic fashion it is possible to ask: what is the relation between the uncanniness of the individual itself and the other individual as a

\footnotetext{
${ }^{28}$ Ibid., 49; Ibid., 61.

${ }^{29}$ For a different answer to this question, see Katherine Withy, "Authenticity and Heidegger's Antigone," in Journal of the British Society for Phenomenology, 45 (2014), 239-253.

${ }^{30}$ It would take another paper to deal with the question of why Heidegger does not speak of the "Fremde" in these lectures and, more generally, of the difference between Heidegger's conception of being-with (Mitsein) and Derrida's thinking of the foreigner. This evolution would become clear only through a comparative reading along with Levinas's work. Cf. Lisa Foran and Rozemund Uljée, Heidegger, Levinas, Derrida: The Question of Difference (Berlin: Springer, 2016).
}

(c) 2021 Diego D'Angelo

https://www.kritike.org/journal/special issue 2021/d'angelo april2021.pdf

ISSN 1908-7330

(c) $\mathrm{BY}-\mathrm{NC}-\mathrm{ND}$ 
foreigner? In order to address and thematize this question, we thus turn to Derrida.

\section{Derrida's Reading of Oedipus at Colonus: Being Foreign}

I will now concentrate on Derrida's reading of Sophocles' Oedipus at Colonus and show that the question Heidegger left open concerning the philosophical meaning of being foreign impinges on the very essence of the human being.

Derrida develops his interpretation of Oedipus at Colonus in a series of lectures in January 1996 in Paris. These lectures have appeared in French with the title De l'hospitalité in 1997 and have been translated into English in 2000. The first lecture bears a title that directly thematizes the question that interests us: "Foreigner Question: Coming from Abroad / from the Foreigner." 31

For Derrida, the question "what does it mean to be foreign?" means asking "the question of the foreigner." But already here Derrida claims a strange point: that the question concerning the foreigner is at the same time "a foreigner's question ... coming from the foreigner, from abroad." ${ }^{32}$ For Derrida, the question about the essence of the foreign cannot be asked in abstracto, but is a question posed by the stranger-for example, in the moment in which he/she arrives in a foreign country seeking asylum, just as Oedipus arrives in Colonus asking King Theseus to receive and accept him.

We become interested in the nature of being foreigner when others enter into our own "home" and ask to be received or when we are the foreigner ourselves. In this concreteness, the question concerning the essence of the foreign becomes the question that the foreigner asks me, the question of being received. How do we answer this question? Derrida points out the fact that we usually respond to the question of the foreigner who is asking for reception with another question: we ask the foreigner's name, we want to know his/her identity, his/her history, the family and the country to which he/she belongs (i.e., in which he/she is not a foreigner). But this signalizes that my hospitality is limited: it seems to depend on the willingness of the foreigner to disclose his/her own identity. In Derrida's own words:

... this foreigner, then, is someone with whom, to receive him, you begin by asking his name; you enjoin him to state and to guarantee his identity, as you would a witness before a court. This is someone to whom you put

\footnotetext{
${ }^{31}$ Jacques Derrida and Anne Dufourmantelle, Of Hospitality: Anne Dufourmantelle Invites Jacques Derrida to Respond, trans. by Rachel Bowlby (Stanford: Stanford University Press, 2000), 3. ${ }^{32}$ Ibid.
} 
a question and address a demand, the first demand, the minimal demand being: "What is your name?" or then "In telling me what your name is, in responding to this request, you are responding on your own behalf, you are responsible before the law and before your hosts, you are a subject in law." 33

At this point, Derrida asks if it is possible to envision an "absolute hospitality," what he also calls "just hospitality," 34 a hospitality that does not ask for something in exchange:

The law of hospitality, the express law that governs the general concept of hospitality, appears as a paradoxical law, pervertible or perverting. It seems to dictate that absolute hospitality should break with the law of hospitality as right or duty, with the "pact" of hospitality. To put it in different terms, absolute hospitality requires that I open up my home and that I give not only to the foreigner (provided with a family name, with the social status of being a foreigner, etc.), but to the absolute, unknown, anonymous other, and that I give place to them, that I let them come, that I let them arrive, and take place in the place I offer them, without asking of them either reciprocity (entering into a pact) or even their names. ${ }^{35}$

It may seem loving and caring to ask for the identity of foreigners and perhaps it is indeed all right. But Derrida points out the fact that, even if in a minimal way, this act of asking the foreigners to identify themselves is an act of violence and imposition of power on someone that cannot really say "no": in such cases we would feel like we have a reason to deny hospitality. We justify the necessity to ask for the name of the stranger because we feel like we cannot render hospitality to someone who is not even ready to reveal their identity.

Therefore, if for Heidegger the essence of the human being has to be formulated as the law of being-foreign, Derrida notes that being foreign presupposes hospitality, and that in turn this law of hospitality is paradoxical, because it implies a pure hospitality besides every positive right, besides every law, even beyond the possibility of asking for something in

\footnotetext{
${ }^{33}$ Ibid., 27.

${ }^{34}$ Ibid., 25.

${ }^{35} \mathrm{Ibid}$.
} 
return-not even the foreigner's name and history. "The law of absolute hospitality commands a break with hospitality by right, with law or justice as rights." 36 This is the paradoxical nature of hospitality: being a law besides actual law.

In order to describe this situation better, Derrida turns to the arrival of Oedipus at Colonus as described at the start of Sophocles' Oedipus at Colonus. It is the last surviving tragedy of the great Greek poet, probably composed when he was 90 years old and presented in the theater only after his death. In this tragedy, Oedipus himself is an old man, and this, along with a number of reasons into which we cannot go at this point, has brought interpreters to find autobiographical elements in the protagonist. ${ }^{37}$

Antigone accompanies the blind and old Oedipus to Colonus, where he wishes to find hospitality and shelter to live his remaining days-which are not many, since at the end of the tragedy he dies and is buried in Colonus, as predicted by the oracle. In the mythology of Thebes, therefore, this story happens before that facts narrated in Antigone, in which Oedipus is already dead and Antigone has left Colonus in order to return to Thebes, where she faces Kreon and his denial to bury the corpse of Polynikes.

Derrida turns his interest to the start of this tragedy precisely because here Oedipus, a stranger, addresses strangers (the people of Colonus) in order to know where he is. He is, according to Derrida's interpretation, "the outlaw" 38 because of his family history. ${ }^{39}$ I think it is necessary to recall the passage wherein Antigone, on behalf of Oedipus, asks the stranger from Colonus to tell her where they are; this scene incarnates precisely the question concerning the essence of the foreigner as the question of the foreigner in the sense Derrida spells out:

${ }^{36}$ Ibid.

${ }^{37}$ See for example Karl Reinhardt, Sophocles (New York: Barnes \& Noble, 1979).

${ }^{38}$ Derrida and Dufourmantelle, Of Hospitality, 35.

${ }^{39}$ In the chapter "Possible Returns: Deconstruction and the Placing of Greek Philosophy" from his book Place, Commonality and Judgment, Andrew Benjamin stresses that the "anomos" (the outlaw) is at the same time "adike" (without justice) and points out that the difference between one's own and the foreigner has to be understood not as diversity but as discontinuity. Andrew Benjamin, Place, Commonality and Judgment: Continental Philosophy and the Ancient Greeks (London: Continuum, 2010), 130. Merging my interpretation and Benjamin's in a single enterprise would require substantial work, but it seems to me that the starting points are common. See in particular the following passage: "There is therefore an implicit threat in Derrida's analysis of Oedipus and law. While there is a sense in which he wants to hold to the real possibility that the 'unconditioned' can be effective, the necessity that there be an outside-and it should be remembered that the outside in question is not one that pertains to the particularity of nomoi, but to the presence of nomos as a transcendental condition and thus to the already present modes of relationality defined by being-in-common and being-in-place-cannot preclude the reciprocal necessity of the inscription of a founding act of violence as that which allows for law (where the latter will always be marked by forms of plurality and contestation)." Ibid.,134.

(c) 2021 Diego D'Angelo

https://www.kritike.org/journal/special issue 2021/d'angelo april2021.pdf

ISSN 1908-7330 
ANTIGONE: Shall I go now and ask what place it is? OEDIPUS: Yes, child, as long as it is habitable.

ANTIGONE: It is even inhabited. But I think there is no need. I can see a man right here close to us .... So say what you think is a good idea, for here he is.

OEDIPUS: Stranger, hearing from this girl who sees for both of us that you have luckily turned up as a messenger to tell us what we are unclear about ....

STRANGER: Before you ask me anything else, get up from that seat. You are on land that is not meant for walking on.

OEDIPUS: What land is it? Is it dedicated to one of the gods, then?

STRANGER: It must not be sat on or dwelt on. It belongs to the goddesses of fear, the daughters of Earth and Darkness. ${ }^{40}$

Oedipus himself is addressed by the people of Colonus as a "wanderer" and as someone who is "not a native." They ask him his name, they ask where he comes from and of which family he is, and he tries to avoid answering in order to guard his "terrible secret." 41

CHORUS: It is dreadful, stranger, to reawaken a bad thing long laid to rest. All the same I am longing to know ....

OEDIPUS: What is this?

CHORUS: ... about that awful pain, irresistibly appearing, that you became embroiled in.

OEDIPUS: In the name of your hospitality (xenias), don't ruthlessly open up what I suffered.

CHORUS: There is a widespread and constant rumor, and I ask, stranger $\left(x e\right.$ ein' $\left.^{\prime}\right)$, to hear it truly told ....

OEDIPUS: I suffered the worst things, strangers, I endured them even willingly, let the gods be witness. 42

${ }^{40}$ Derrida and Dufourmantelle, Of Hospitality, 37.

${ }^{41}$ Ibid., 39.

${ }^{42}$ Ibid., 41.

(c) 2021 Diego D'Angelo

https://www.kritike.org/journal/special issue 2021/d'angelo april2021.pdf

ISSN 1908-7330 
At this point in the tragedy, we see that Oedipus is asked by the Chorus of old, native inhabitants of Colonus to reveal his name and his secret history. The arrival of Theseus, king of Colonus, is represented as the encounter between two strangers: both stranger to each other, but also both strangers in Colonus, since Theseus himself arrived there from a foreign land many years before Oedipus.

Now Derrida points out that the question that accompanies us - what does it mean to be foreigner? - is a question that presupposes a dichotomy between the foreign and one's own, a dichotomy that is problematic:

Nowadays, a reflection on hospitality presupposes, among other things, the possibility of a rigorous delimitation of thresholds or frontiers: between the familial and the non-familial, between the foreign and the non-foreign, the citizen and the non-citizen, but first of all between the private and the public, private and public law, etc. ${ }^{43}$

But precisely this is not possible, since it is not at all clear on the basis of what other concepts we should draw such thresholds and frontiers. This is shown in an exemplary way by the figure of Theseus, king of Colonus (and therefore its most excellent citizen) but at the same time a foreigner himself. How can we draw a line, a frontier, between home and foreign?

In the end, the question of frontiers is precisely the question of the foreigner we are asking, and in doing so we find ourselves necessarily caught within a logical circle from which there is no escape: in order to define the foreign, we need to define frontiers, which can only happen on the basis of a distinction between foreign and own's one, and so on ad infinitum. The same dialectical tension pervades hospitality itself:

No hospitality, in the classic sense, without sovereignty of oneself over one's home, but since there is also no hospitality without finitude, sovereignty can only be exercised by filtering, choosing, and thus by excluding and doing violence. Injustice, a certain injustice, and even a certain perjury, begins right away, from the very threshold of the right to hospitality. ${ }^{44}$

${ }^{43}$ Ibid., 47, 49

${ }^{44}$ Ibid., 55. 


\section{TO BE OR NOT TO BE}

Now, Oedipus arrives in Colonus with the explicit desire to respect the sovereignty of Theseus over the city. He and his daughters (Antigone and Ismene) repeatedly state in the play that they will do as the inhabitants of Colonus will say. But at the same time, Oedipus arrives in Colonus with a precise idea: he wants to follow the oracle that predicted that Oedipus will die in Colonus, and that his death would bring salvation to the city. Oedipus also has very clear ideas concerning the way in which he wants to be buried, most notably that there should be no tombstone marking the place of his burial. Is Theseus bound to accept Oedipus's requests by the laws of hospitality? Or should Oedipus accept to be buried according to the funeral laws of Colonus? In other words and more generally, one could ask: what are the norms, the rights and duties, for hosts and guests?

Precisely here Derrida shows (as is typical of his philosophical style) that the very concept of hospitality implies an unsolvable paradox:

... there would be an antinomy, an insoluble antinomy, a non-dialectizable antinomy between, on the one hand, The law of unlimited hospitality (to give the new arrival all of one's home and oneself, to give him or her one's own, our own, without asking a name, or compensation, or the fulfillment of even the smallest condition), and on the other hand, the laws (in the plural), those rights and duties that are always conditioned and conditional. ${ }^{45}$

These plural laws are the concrete laws that define hospitality in a certain country. The ideal of perfect hospitality would require the host to accept the guest and the foreigner without any boundaries, without asking for the name, but just according to the foreigner's desires - such as of being buried on foreign ground without a tombstone.

Derrida shows some examples of this kind of unlimited hospitality in an interpretation of the Biblical narratives of Lot, who is willing to protect his guests up to the point of giving up his virgin daughters for them. Interestingly, the example of Lot is needed in order to show that Derrida's philosophy of hospitality is no naive theory of unlimited hospitality. He rather wants to state the tension that is implied in the concept itself. Lot is the example of someone who "puts the laws of hospitality above all, in particular the ethical obligations that link him to his relatives and family, first of all his daughters." 46 And in Lot's way of handling this situation, the sexual

${ }^{45}$ Ibid., 77.

${ }^{46}$ Ibid., 151.

(c) 2021 Diego D'Angelo

https://www.kritike.org/journal/special issue 2021/d'angelo april2021.pdf

ISSN 1908-7330

(c) BY-NC-ND 
difference plays a crucial role; ${ }^{47}$ but, Derrida asks, the concept of hospitality we have inherited could be a direct heir of the horrible deeds of Lot: "Are we the heirs to this tradition of hospitality? Up to what point? Where should we place the invariant, if it is one, across this logic and these narratives? They testify without end in our memory." 48 These are the very last words of Derrida's book. ${ }^{49}$

This tension between an ideal hospitality that can be gruesome in its unboundedness and the limited laws of hospitality is therefore not something we should discard, but something we should inhabit: "Between an unconditional law or an absolute desire for hospitality on the one hand and, on the other, a law, a politics, a conditional ethics, there is distinction, radical heterogeneity, but also indissociability." 50 Inhabiting means in this case also to take seriously what some texts of the tradition (Oedipus at Colonus, the Bible) testify in regard to hospitality. If Lot is a symbol of an unbounded hospitality, Theseus, for Derrida, is a symbol of a middle way that can be ethically correct: Theseus asks Oedipus about his name and his history, but is ready to give something in exchange, that is, to accept Oedipus and his funeral wishes without conditions, and he even accepts the burden of being the only one that knows the secret of Oedipus's burial place. Theseus is therefore, in Derrida's reading, the one who inhabits the tension in the right way - maybe because he is himself a foreigner in Colonus and knows what it means to be a foreigner. Derrida writes:

We will always be threatened by this dilemma between, on the one hand, unconditional hospitality that dispenses with law, duty, or even politics, and, on the other, hospitality circumscribed by law and duty. One of them can always corrupt the other, and this capacity for perversion remains irreducible. It must remain so. It is true that this abstention ("come, enter, stop at my place, I don't ask your name, nor even to be responsible, nor where you come from or where you are going") seems more worthy of the absolute hospitality that offers the

\footnotetext{
47 The fact that Derrida speaks himself of the role of the sexual difference in the contest of his interpretation of Lot does not contradict Rachel Bowlby's correct observation that Derrida seems to forget the role of Ismene and Antigone as female figures in his reading of Oedipus at Colonus. See Rachel Bowlby, "Derrida's Dying Oedipus," in Derrida and Antiquity, ed. by Miriam Leonard (Oxford: Oxford University Press, 2010), 187-206.

48 Derrida and Dufourmantelle, Of Hospitality, 153.

49 For a more comprehensive account of Derrida's interpretation of the figure of Lot, see Judith Still, Derrida and Hospitality: Theory and Practice (Edinburgh: Edinburgh University Press, 2012), 51-92.

${ }^{50}$ Derrida and Dufourmantelle, Of Hospitality, 147.
} 
gift without reservations; and some might also recognize there a possibility of language. Keeping silent is already a modality of possible speaking. ${ }^{51}$

There is much more to be said about these passages. However, the scope of this article is limited. I would like to conclude here and point out the way in which I think Derrida's interpretation of hospitality in Oedipus at Colonus can be read as complementing Heidegger's reading of Antigone-and what philosophical consequences can be drawn from this.

\section{Conclusion}

What Heidegger spells out as the law of the human being, that is, the necessity of not-being-at-home, is shown by Derrida to be impossible, or at least to imply some kind of violence to the foreigner. Is it possible to solve this tension? Here, I will show that the impossible definition of the human being as "not-being-at-home" does not represent a tension to be conceptually solved, but a tension we need to live in and "make our own": by accepting our constitutive foreignness we can open up a realm where absolute hospitality becomes possible again.

The impossibility of the law of hospitality as individuated by Derrida resides in the impossible necessity to render hospitality without asking questions, without even asking for the name of the foreigner, allowing him/her to keep his/her own secrets. But another way, which Derrida interestingly does not thematize himself, is possible. Instead of asking questions, we can simply let the foreigner speak for himself/herself. Without forcing our sovereignty upon them, it is possible to wait for them to find the right moment and the right time to disclose their secrets and to reveal their names. ${ }^{22}$ By opening up a space in which a dialogue is possible, but without forcing the foreigner to a dialogue through questions, we can show openness for a loving and caring relationship to the foreigner by adapting ourselves, but transforming our way of life in such a way that hospitality does not require, as for Oedipus, that he accepts the law of the country which is to render him hospitality, but rather where hospitality does not require anything from the foreigner; it just requires something from the host: to wait and let the foreigner speak if and when he/she wishes to. Caring for the foreigner thus becomes an irreducible aspect of the way in which we should

${ }^{51}$ Ibid., 135.

${ }^{52}$ A similar idea, although from a theological perspective, has been developed in a close reading of Derrida and Levinas by Andrew Shepherd. See Andrew Shepherd, The Gift of the Other: Levinas, Derrida, and a Theology of Hospitality (Princeton: Pickwick Publications, 2014).

(c) 2021 Diego D'Angelo

https://www.kritike.org/journal/special issue 2021/d'angelo april2021.pdf

ISSN 1908-7330

(c) BY-NC-ND 
build the world we inhabit and embrace the essence of the human being as a being constitutively not-at-home.

Our reading of Heidegger's concept of being-at-home by way of a comparison and development through Derrida's question of the foreigner has thus shown consequences that go beyond a mere confrontation between two authors in the history of philosophy; it has shown that, if thought through, hospitality is not a request coming from the foreigner and directed to the host, but something that the host must achieve by himself/herself: accepting the not-being-at-home that belongs to the human being as such.

Institut für Philosophie, Universität Würzburg, Germany

\section{References}

Benjamin, Andrew, Place, Commonality and Judgment: Continental Philosophy and the Ancient Greeks (London: Continuum, 2012).

Bowlby, Rachel, "Derrida's Dying Oedipus," in Derrida and Antiquity, ed. by Miriam Leonard (Oxford: Oxford University Press, 2010), 187-206.

D'Angelo, Diego, "Das Gesetz des Ortes. Ein Versuch über Heidegger und Sophokles," in Regelfolgen, Regelschaffen, Regeländern: Die Herausforderung für Auto-Nomie und Universalismus durch Ludwig Wittgenstein, Martin Heidegger und Carl Schmitt, ed. by Manuela Massa, James Thompson, Stefan Knauß, and Matthias Kaufmann (Berlin: Peter Lang, 2020), 19-34.

Derrida, Jacques and Anne Dufourmantelle, Of Hospitality: Anne Dufourmantelle Invites Jacques Derrida to Respond, trans. by Rachel Bowlby (Stanford: Stanford University Press, 2000).

Figal, Günter, Diego D'Angelo, Tobias Keiling, and Guang Yang eds., Paths in Heidegger's Later Thought (Bloomington: Indiana University Press, 2020).

Fleming, Katie, "Heidegger's Antigone: Ethics and Politics," in Tragedy and the Idea of Modernity, ed. by Joshua Billings and Miriam Leonard (Oxford: Oxford University Press, 2015).

Foran, Lisa and Rozemund Uljée, Heidegger, Levinas, Derrida: The Question of Difference (Berlin: Springer, 2016).

Heidegger, Martin, Hölderlins Hymne "Der Ister" (Frankfurt am Main: Klostermann, 1984).

Hölderlin's Hymn "The Ister," trans. by William McNeill and Julia Davis (Bloomington: Indiana University Press, 1996).

The Fundamental Concepts of Metaphysics: World, Finitude, Solitude, trans. by William McNeill and Nicholas Walker (Bloomington: Indiana University Press, 2001).

(C) 2021 Diego D'Angelo

https://www.kritike.org/journal/special issue 2021/d'angelo april2021.pdf

ISSN 1908-7330

(cc) BY-NC-ND 


\section{TO BE OR NOT TO BE}

Pathmarks (Cambridge: Cambridge University Press, 2008).

"Why Do I Stay in the Provinces?" in Heidegger: The Man and the Thinker, ed. by Thomas Sheehan (New York: Routledge, 2009).

Hyland, Drew A. and John P. Manoussakis, Heidegger and the Greeks: Interpretative Essays (Bloomington: Indiana University Press, 2006).

Leonard, Miriam ed., Derrida and Antiquity (Oxford: Oxford University Press, Oxford 2010).

Plato, Euthyphro, Apology, Crito, Phaedo, Phaedrus, ed. by H. N. Fowler (Cambridge: Harvard University Press, 2017).

Pöggeler, Otto, Schicksal und Gedichte: Antigone im Spiegel der Deutungen und Gestaltungen seit Hegel und Hölderlin (München: Fink Verlag, 2004).

Reinhardt, Karl, Sophocles (New York: Barnes \& Noble, 1979).

Shepherd, Andrew, The Gift of the Other: Levinas, Derrida, and a Theology of Hospitality (Princeton: Pickwick Publications, 2014).

Still, Judith, Derrida and Hospitality. Theory and Practice (Edinburgh: Edinburgh University Press, 2010).

Swazo, Norman K., "'Preserving the Ethos': Heidegger and Sophocles' Antigone," in Symposium, 10 (2006), 441-471.

Vukićević, Vladimir, Sophokles und Heidegger (Stuttgart/Weimar: Verlag J. B. Metzler, 2003).

Withy, Katherine, "Authenticity and Heidegger's Antigone," in Journal of the British Society for Phenomenology, 45 (2014), 239-253.

(c) 2021 Diego D'Angelo

https://www.kritike.org/journal/special issue 2021/d'angelo april2021.pdf

ISSN 1908-7330

(cc) BY-NC-ND 